\title{
Remote Sensing and GIS Application to Erosion Risk Mapping in Lagos
}

\author{
Makinde E.O ${ }^{1,2, *}$ and Oyebanji E.I ${ }^{2}$ \\ ${ }^{1}$ KITE Group, Environment Department, University of York, UK \\ ${ }^{2}$ Department of Surveying and Geoinformatics, University of Lagos, Akoka, Lagos state, Nigeria \\ *Corresponding Author: estherdanisi@gmail.com; eomakinde@unilag.edu.ng
}

https://doi.org/10.36263/nijest.2020.01.0081

\begin{abstract}
Increased population, unhealthy agricultural practices, indiscriminate land clearing and illegal structures have led to an increase of erosion in Nigeria and Lagos State in particular. This research focused on identifying land use/land cover changes in Eti-Osa LGA of Lagos State and estimating the actual erosion risk using Remote Sensing and Geography Information System. In addition, this research evaluated the perception of communities within the study area with the view to understanding the risk involved in erosion. Maximum Likelihood Algorithm was the classification method applied on the Landsat imageries (1986-2016) to identify the changes on the land use/land cover types. Analysis of Variance (ANOVA) was used to evaluate the perception of communities within the study area and Revised Universal Soil Loss equation (RUSLE) model was used to estimate the actual erosion risk. The result showed that the sediment yield of the study area was estimated to be between 0 to 48ton/ha/yr. The estimated soil losses were higher in Eti-Osa West compared to other parts of Iru/Victoria Island, and Ikoyi/Obalende areas which recorded low losses. Land uses mostly affected by very high and severe erosion are the bare soils and the crop lands having about 3\% to $4 \%$ respectively. It can be concluded that rainfall, lack of cover for the surface soil were the major causes of soil loss in the study area.
\end{abstract}

Keywords: Remote Sensing, Geographic Information System, Risk Mapping, Soil Erosion, RUSLE, Nigeria Meteorological Agency (NiMet), Shuttle Radar Topographic Mission (SRTM), Landsat images

\subsection{Introduction}

Coastal erosion is experienced in almost all the sections of Nigeria's coastal zone, thus the quest for a lasting solution (Etuonovbe, 2006). The social and economic consequences of coastal erosion can be substantial in many cases such as causing dis3placement of a whole community, including the loss of lives, loss of port facilities, infrastructures, recreational facilities, industrial and residential land due to coastal erosion as the case with Ogulaha community in Forcados South Point, Delta State, Nigeria (Etuonovbe, 2006). In coastal cities, certain important factors such as rainfall amount and precipitation intensity, which are called rainfall erosivity can results into soil erodibility IPCC (2007).The consequences of these have been reflected in the severe loss of lives and properties especially in Lagos State where the coastal zone contributes to a major part of the nation's income (Etuonovbe, 2006).

Assessing the soil erosion rate is essential for the development of adequate erosion prevention measures for sustainable management of land and water resources (Alaaddin et al., 2008). Pandey et al., (2007) describe soil erosion as serious environmental problem as it removes soil rich in nutrients and increases natural level of sedimentation in the rivers and reservoirs reducing their storage capacity and life span. In urban areas like Lagos, population explosion, rapid urbanization, climate change, increased rainfall, poor agricultural practices etc. are factors that contribute to soil 
erosion, it is also of universal importance as man's activities, directly or indirectly, depend on the soil. Soil erosion thus constitutes a national hazard, which containment is a prerequisite to national development (Isikwue et al., 2012).

Different models have been adopted to assess and study soil erosion. The Universal Soil Loss Equation (USLE) model was suggested first based on the concept of the separation and transport of particles from rainfall in order to calculate the amount of soil eroded in agricultural areas (Wischmeier and Smith, 1965).The USLE has been enhanced during the past 30 years by a number of researchers to Modified Universal Soil Loss Equation (MUSLE) and Revised Universal Soil Loss Equation RUSLE (Williams, 1975, Renard et al., 1997).RUSLE added many factors such as the revision of the weather factor, the development of the soil erosion factor depending on seasonal changes, the development of a new calculation procedure to calculate the cover vegetation factor, and the revision of the length and gradient of slope (Renard et al., 1997).

Remote sensing (RS) is the science of obtaining data/information about the earth's surface without directly being in contact with it, this is done by sensing and recording reflected and emitted energy and processing, analyzing, and applying that information (Sabins, 1997). Geographic Information System (GIS) is an arrangement of computer hardware, software, and geographic data that people interact with to integrate, analyze, and visualize data; identify relationships, patterns, and trends; and find solutions to problems. The system is designed to capture, store, update, manipulate, analyze, and display studied data and used to perform analyses (ESRI, 2005).The Remote Sensing (RS) technology has been used to provide the land use/cover information by using digital image processing techniques (Alaaddin et al., 2008). There have been many studies on modeling soil erosion by utilizing Remote Sensing and Geographic Information System (GIS) technologies (Demirci et al., 2012; Ganasri et al.,2016).The capabilities of these technologies even increase when they are integrated with empirical erosion prediction models (Alaaddin et al., 2008). While soil erosion models only calculate the amount of soil erosion based on the relationships between various erosion factors, Remote Sensing and Geographic Information System (GIS) integrated erosion prediction models do not only estimate soil loss but also provide the spatial distributions of the erosion (Alaaddin et al., 2008). Generating accurate erosion risk maps in Geographic Information System (GIS) environment is very important to locate the areas with high erosion risks and to develop adequate erosion prevention techniques (Alaaddin et al., 2008).Sazbo et al.,(1998) conducted a study where Remote Sensing and GIS technologies were successfully used for land degradation and erosion mapping. Another study by Bojie et al., (1995) also indicated that Geographic Information System (GIS) analysis provide satisfactory results in developing erosion surveys and risk maps by using Geographic Information System (GIS) data layers such as DEM, slope, aspect, and land use (Alaaddin et al., 2008).This paper assessed the problem of erosion in Eti-Osa Local Government Area, Lagos State, Nigeria, mapped out areas prone to erosion, and assessed the perception of occupants and their interplay in the study area. This research work applied RS and GIS techniques in modeling erosion in the study area.

\subsection{Materials and Methods}

\subsection{The study Area}

Eti-Osa Local Government Area is located between $6^{0} 15^{\prime}$ and $6^{0} 17^{\prime}$ and longitude $3^{0} 3^{\prime}$ East and $3^{0}$ 3' East. It is bounded in the south by Atlantic Ocean, in the east by Ojo Local government, north by Lagos lagoon and part of Mainland and Island local government and in the west by Ibeju-Lekki Local Government (Odumosu et al., 1999).

The topography is between $3-15 \mathrm{~m}$ above sea level (Akoteyon and Soladoye, 2011). The geology consists of quaternary alluvial deposits such as red-yellow, red-brown, grey and sandy-clays, silt, sand, gravels, and other detrital material (Akoteyon and Soladoye, 2011).The study area occupies an area of about $193.460 \mathrm{~km}^{2}$ (National Population Commission, 2006). The population is about 283,791 
with density of 1,467 people per $\mathrm{km}^{2}$ (National Population Commission, 2006). The climate is tropical type with an average rainfall of $2500 \mathrm{~mm}$ and temperature of $30^{\circ} \mathrm{C}$ (Akoteyon and Soladoye, 2011). The vegetation pattern reflects its coastal location with mangrove swamp trees being the dominant type (Akoteyon and Soladoye, 2011).

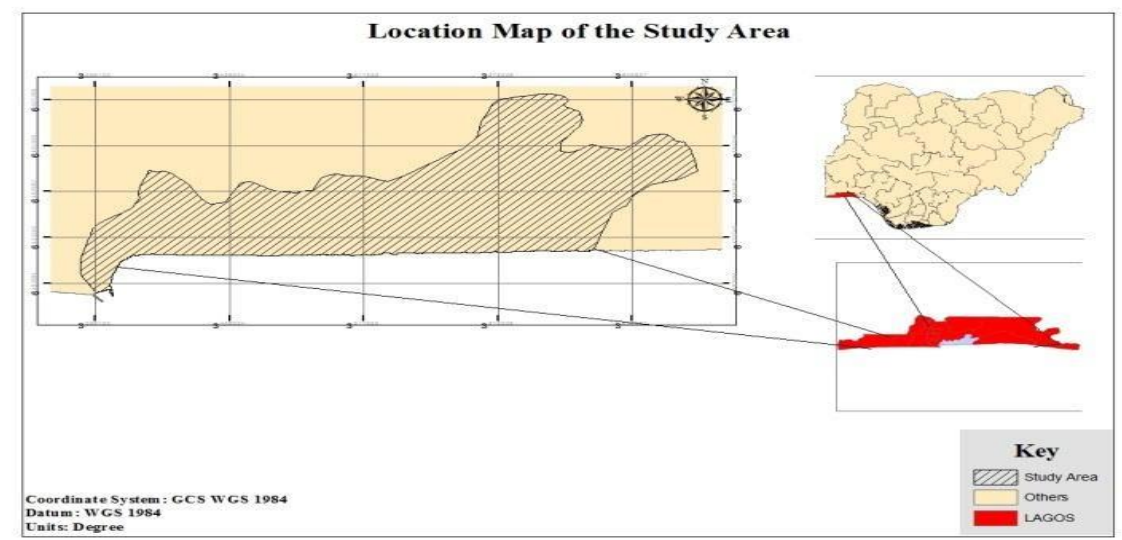

Figure 1: Map of the location of the Study Area

\subsection{Data Acquisition and Processing}

The data used in executing this study are of three groups: satellite imageries, field data and questionnaires. Landsat images (30m) for 1986, 2000, 2002, 2006 and 2016 (Table 1) were obtained from Global land cover facilities (http://www.glovis.usgs.gov/) and subjected to digital image processing (DIP). Maximum Likelihood Algorithm was the classification techniques performed on the images and thus a land use/cover management and support practice maps were produced. And subsequently, the cover management factor $(\mathrm{C})$ and support practice factor $(\mathrm{P})$ were estimated. The utilization of data include: soil data from soil test, hydrological data from Nigeria Meteorological Agency (NiMet), Shuttle Radar Topographic Mission (SRTM) data for DEM and Landsat images. The soil data was obtained from soil test carried out at the Department of Civil Engineering, University of Lagos and the precipitation data from Nigerian Meteorological Agency. The soil test data was reprocessed into a rasterized soil map, delineating six different soil types in Eti-Osa Local Government.

Table 1: Acquisition dates of the Landsat Imageries used

\begin{tabular}{llcc}
\hline Year & Sensor & Spatial Resolution & Acquisition Date \\
\hline 1986 & Landsat 5 TM & $30 \mathrm{~m}$ & December 24 \\
2000 & Landsat 7 ETM+ & $30 \mathrm{~m}$ & February 6 \\
2002 & Landsat 7 ETM+ & $30 \mathrm{~m}$ & December 28 \\
2006 & Landsat 7 ETM+ & $30 \mathrm{~m}$ & December 7 \\
2016 & Landsat 8 OLI & $30 \mathrm{~m}$ & December 26 \\
\hline
\end{tabular}

\subsection{Soil Erosion Risk Mapping using RUSLE Model}

The revised universal soil loss equation (RUSLE) was used to assess the areas of erosion risk in the study area. The RUSLE equation is defined by the following parameters (Zhang et al., 2004; Wischmeier, 1979).

$$
\mathrm{A}=\mathrm{R} \times \mathrm{K} \times \mathrm{L} \times \mathrm{S} \times \mathrm{C} \times \mathrm{P}
$$


Where: $\mathrm{A}=$ average soil loss; $\mathrm{R}=$ erosivity factor (derived from rainfall data); $\mathrm{K}=$ soil erodibility factor (derived from soil data); $\mathrm{L}=$ slope length factor (obtained from DEM); $\mathrm{S}=$ slope steepness factor (obtained from DEM); $\mathrm{C}=$ cover management factor and $\mathrm{P}=$ support practice factor.

\subsection{Calculation of RUSLE Factors}

\subsubsection{Rainfall - Runoff Erosivity (R)}

Rainfall and runoff (volume, peak discharge) are factors of erosivity (Wischmeier and Smith, 1978; Arnoldus, 1980). Roose (1977) model for estimating values of rainfall erosivity from rainfall amounts for West African climates was adopted. The equation is given as:

$\mathrm{R}=(0.55 \times \mathrm{Pa})$

where: $\mathrm{R}$ is the rainfall erosivity factor [MJ mm ha-1h-1yr-1], $\mathrm{Pa}$ is the Annual average rainfall amount (mm).

The long-term non recording rain gauge data ranging from 1986 to 2014 were used to compute long term averages for the study area. Each of the rainfall charts was analyzed by summing up the monthly averages to the yearly averages. To obtain rainfall amount in $\mathrm{mm}$, the rainfall from January December averages years, the values of the rainfall records in the study (Table 2) were used to generate the rainfall map. $\mathrm{R}$ factor was determined for the selected rainfall gauging stations using the Equation 2 above. However, due to data gaps, the available data was projected for the two stations and their averages used and the rainfall map (Figure 2) extracted. Isohyet maps for $\mathrm{R}$ factor were generated using ArcGIS10.2.

Table 2: Surrounding Rainfall Stations and their Annual Averages

\begin{tabular}{clcccc}
\hline No & Stations & $\mathrm{X}$ & $\mathrm{Y}$ & Annual Average & R Factor \\
\hline 1 & Lagos Marine & 3.4 & 6.41667 & 202.0917 & 111.15 \\
2 & Lagos Roof & 3.430933 & 6.441077 & 129.275 & 71.1 \\
\hline
\end{tabular}

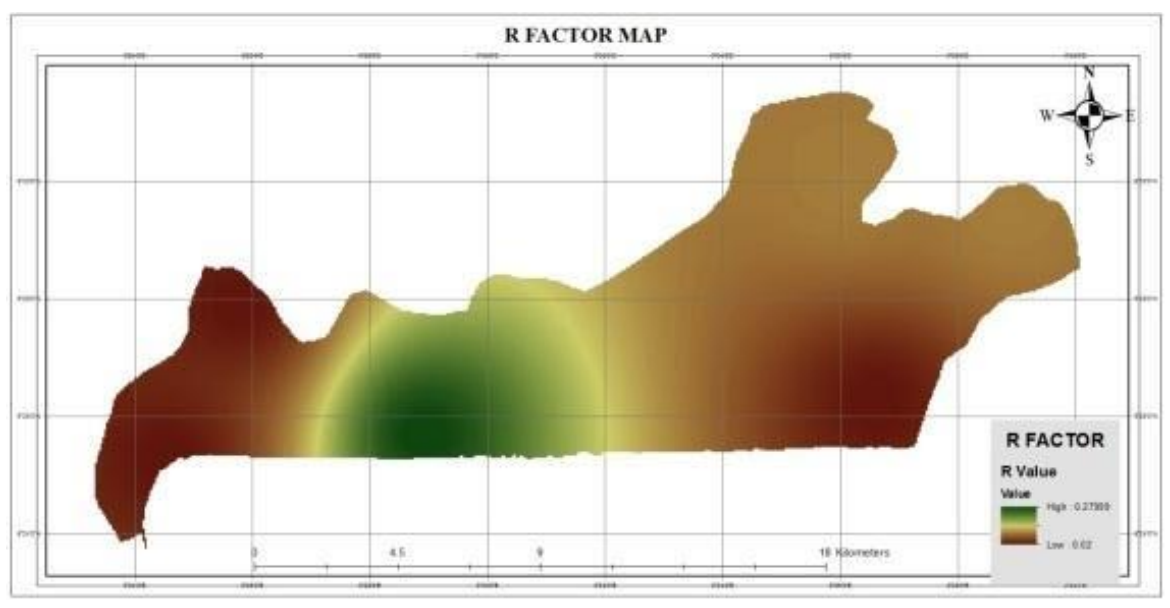

Figure 2: R Factor Map

\subsubsection{Soil Erodibility Factor (K)}

Soil erodibility $(\mathrm{K})$ represents the susceptibility of soil or surface material to erosion, transportability of the sediment, and the amount and rate of runoff given a particular rainfall input, as measured under 
a standard condition (Weesies, 1998. For a standard plot as earlier defined, soil erodibility factor, K, is calculated from the equation:

$\mathrm{K}=\mathrm{A} / \mathrm{R}$

where: A is amount of soil loss and; R is rainfall erosivity factor in the USLE (Wischmeier and Smith, $1965 ; 1969)$.

For this study, soil samples of various horizons (and based on stratified random sampling technique) were collected from these locations: Ajah roundabout, Badore axis, Sangotedo axis, Ogomu axis, Ikoyi/Obalende axis and Iru/Victoria-island axis and analyzed in the Laboratory of the Department of Civil Engineering, University of Lagos to correctly assign soil erodibility values (Table 3). These soil samples were assessed using the Wischmeier et al., (1971) nomograph. The nomograph relates the K factor to five soil profile parameter (Zhang, et al., 2012). The soil properties - percentage of silt $(0.002-0.05 \mathrm{~mm})$ plus percentage of very fine sand $(0.05-0.01 \mathrm{~mm})$ and the percentage of sand $(0.1-$ $2 \mathrm{~mm}$ ) needed for the estimation of $\mathrm{K}$ using the nomograph was adopted from Agada (2015). The estimated soil erodibility laboratory test result ranged from 0.02 to 0.28 (Table 4). For this study, K factor shape file was added as a layer into ArcGIS 10.2, the soil map attribute table was edited by adding a new field of $\mathrm{K}$ values under the Edit menu at attribute view before $\mathrm{K}$ factor was produced (Figure 3). The $\mathrm{K}$ factor for the various soil classes was added.

Table 3: Soil Sample

\begin{tabular}{lccc}
\hline \multirow{2}{*}{ Soil sample stations } & \multicolumn{3}{c}{ Soil percentage (\%) } \\
\cline { 2 - 4 } & Sand & Silt & Gravel \\
\hline Eti-osa & 99 & 1 & - \\
Badore & 99 & - & 1 \\
Sangotedo & 99 & - & 1 \\
Ogomu & 97 & - & 3 \\
Ikoyi/Obalende & 94 & 5 & 1 \\
Iru/Victoria-Island & 97 & - & 3 \\
\hline
\end{tabular}

Table 4: K Factor

\begin{tabular}{lc}
\hline Soil Type & K factor \\
\hline Sand & 0.02 \\
Fine sand & 0.1 \\
Very fine sand & 0.28 \\
\hline
\end{tabular}

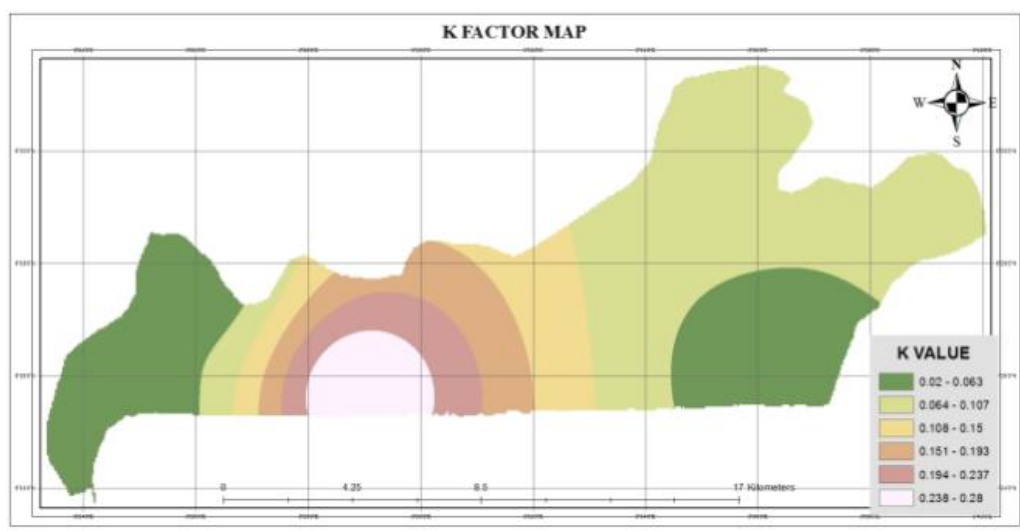

Figure 3: K Factor Map 


\subsubsection{Slope Length and Steepness Factor (LS)}

The effect of topography on soil erosion is accounted for by the LS factor in RUSLE, which combines the effects of a slope length factor, L, and a slope steepness factor, S (Zhang et al., 2012. As the slope steepness (S) increases, the velocity and erosivity of runoff increase. Slope length (L) is defined as the ratio of soil loss from the field slope length to that from a $22.1 \mathrm{~m}$ length under otherwise identical conditions (Wischmeier and Smith, 1978). The L and S factors are usually considered as single topographical factor and can be estimated using the equation:

$\mathrm{LS}=(\mathrm{x} / 22.13)^{\mathrm{m}}\left[\left(0.065+0.045(\mathrm{~s})+0.0065\left(\mathrm{~s}^{2}\right)\right]\right.$

where: LS is topographical factor and is dimensionless, $\mathrm{x}$ is slope length (meter), $\mathrm{m}$ is an exponent whose value depends slope gradient and, $\mathrm{s}$ is slope gradient (percent), Current recommendations (Wischmeier and Smith, 1978) for the exponent $\mathrm{m}$ are as follows: $\mathrm{m}=0.5$ if slope $\geq 5$ percent, $\mathrm{m}=$ 0.4 if slope $<5$ percent and $>3$ percent, $m=0.3$ if slope $\leq 3$ percent and $\geq 1$ percent, $m=0.2$ if slope $<1$ percent.

$\mathrm{x}=($ flow accumulation $\times$ cell value $)$

By substituting $x$ value, $L S$ equation will be:

$\mathrm{LS}=\frac{(\text { Flow Accumulation } x \text { Cell Value })^{m}\left[\left(0.065+0.045(\mathrm{~s})+0.0065\left(\mathrm{~s}^{2}\right)\right]\right.}{22.13}$

The DEM of the study area was extracted from shuttle radar topographic mission data. This was achieved by using the extraction by mask Spatial Analyst tool of ArcGIS. DEM represents the surface terrain of the study area and permits to retrieve geographical information. Slopes of DEM in percentage were also generated using Surface Analysis under the Spatial Analyst function. Surfacing function was used to generate a DEM and to represent as a surface or one-band image file where the value of each pixel was a specific elevation value. A gray scale was used to differentiate variations in terrain. The Slope map was generated in ArcGIS 10.2 software by using DEM. As the first step, the elevation value was modified by filling the sinks in the grid. This is done to avoid the problem of discontinuous flow when water is trapped in a cell, which is surrounded by cells with higher elevation. This was done by using the Fill tool under Hydrology section found under Spatial Analyst Tool Function in ArcGIS 10.2. Then, Flow direction was generated from the Fill grid. The Flow direction tool takes a terrain surface and identifies the down-slope direction for each cell. This grid shows the on surface water flow direction from one cell to one of the eight neighboring cells. This was done by using the Flow direction tool under Hydrology section found under Spatial Analyst Tool Function in ArcGIS. Based on the Flow direction, Flow accumulation was calculated (Figure 4). Flow accumulation tool identifies how much surface flow accumulates in each cell; cells with high accumulation values are usually stream or river channels. It also identifies local topographic highs (areas of zero flow accumulation) such as mountain peaks and ridgelines. This was done by using the Flow accumulation tool under Hydrology section found under Spatial Analyst Tool Function in ArcGIS 10.2. Finally, the Raster calculator function under Spatial Analyst feature (Map Algebra) was used to input the equation 4 to compute LS factor. Themes of slope of DEM in percentage and flow accumulation were activated to run the process as shown in equation 5 and 6 . Cell value of $20 \mathrm{~m}$ was utilized in Equation 5. The $\mathrm{m}$ value of 0.5 was selected for equation 4 because about $80 \%$ of the terrain of the study was steeper than $20^{\circ}$. LS values ranged from 0 to 12.83 . 


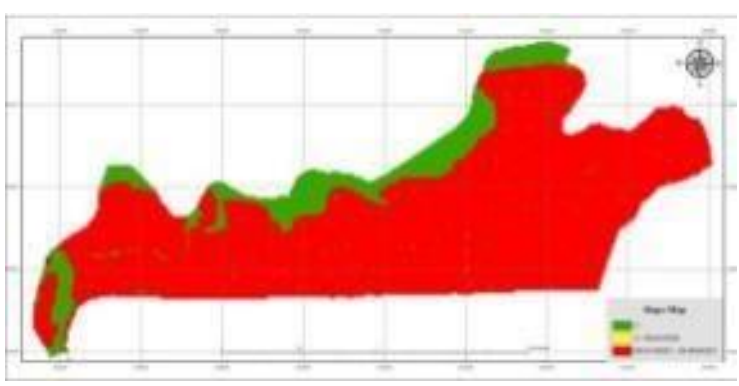

(a) Slope Map



(c) Flow Direction

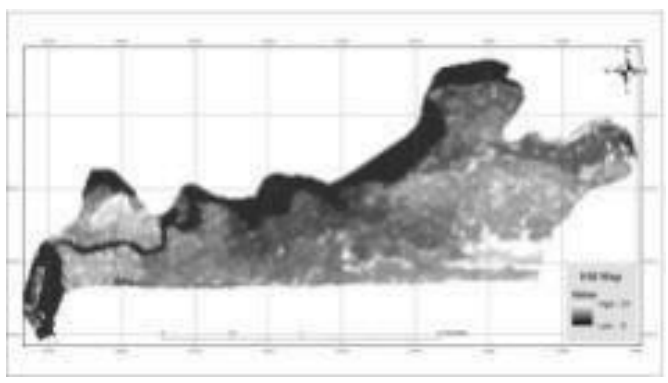

(b) Fill Map

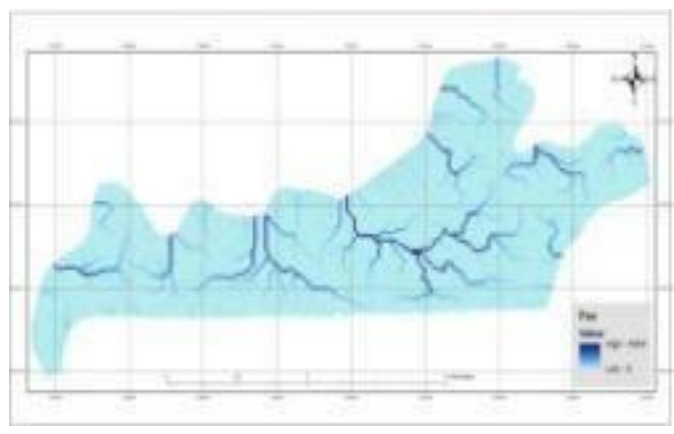

(d) Flow Accumulation

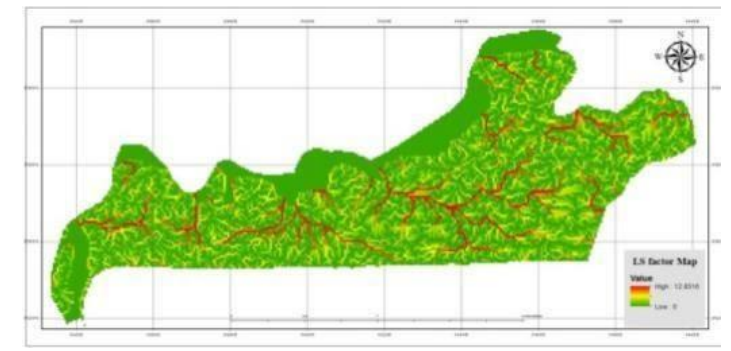

(e) LS Factor Map

Figure 4: Maps predicted from SRTM DEM - (a) Slope Map, (b) Fill Map, (c) Flow Direction and (d) Flow Accumulation (e) LS Factor Map

\subsubsection{Cover Management Factor (C)}

The cover management factor $(\mathrm{C})$ represents the effects of vegetation, management, and erosion control practices on soil loss (Narain et al.,1994). As with other RUSLE factors, the C value is a ratio comparing the existing surface conditions at a site to the standard conditions of the unit plot. RUSLE uses a sub factor method to compute soil loss ratios (SLR), which are the ratios of soil loss at any given time in the cover management sequence to soil loss from the standard condition. The sub factors used to compute a soil loss ratio value are prior land use, canopy cover, surface cover, surface roughness, and soil moisture (Renard et al., 1991). C value is equal to 1 when the land has continuous bare fallow and have no coverage. $\mathrm{C}$ value is lower when there is more coverage of a crop for the soil surface resulting in less soil erosion (Soo, 2011). Characteristics of the land surface, including natural and artificial cover were considered. Existing land use practices were investigated through field survey, and training sites for different land uses were marked to derive information about land use activities and land cover for plotting land use land (LULC) cover map. A maximum likelihood supervised classification was then applied to the imagery using the ArcGIS 10.2 software with the following training sites namely; Built-up, Water body, Light Forest, Bare land and Swampy. From the LULC map (Figure 5) derived $C$ factor values were assigned for the various classes (Table 5) based on previous research findings (Lee and Lee, 2006) and a C factor map (Figure 6) was produced. 
Table 5: Cover and Management Factor Values (Adapted from Lee and Lee, 2006)

\begin{tabular}{clc}
\hline Code & Land Use & C Factor \\
\hline 1 & Water body & 0.000 \\
2 & Bare land & 0.500 \\
3 & Built up & 0.003 \\
4 & Light Forest & 0.050 \\
5 & Swampy & 0.002 \\
\hline
\end{tabular}

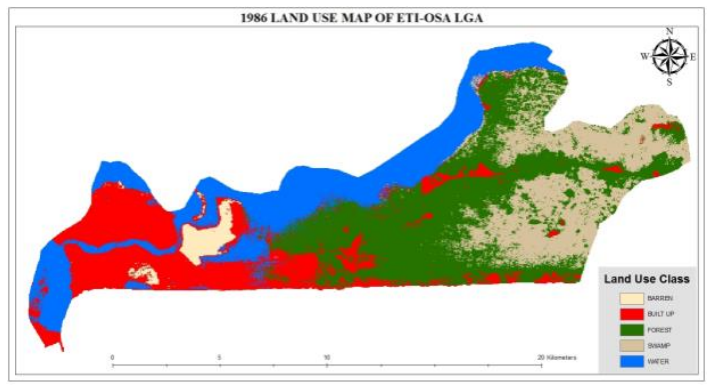

(a)



(c)

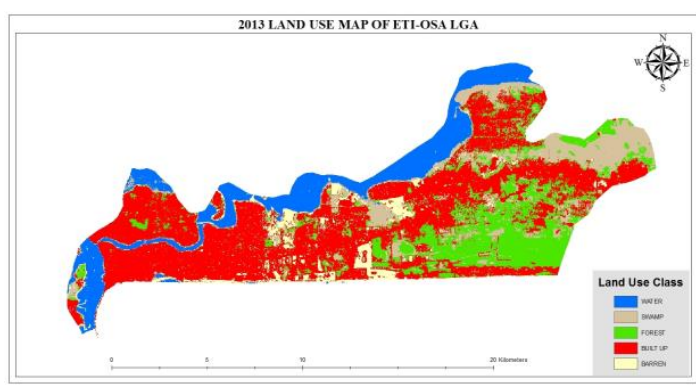

(e)

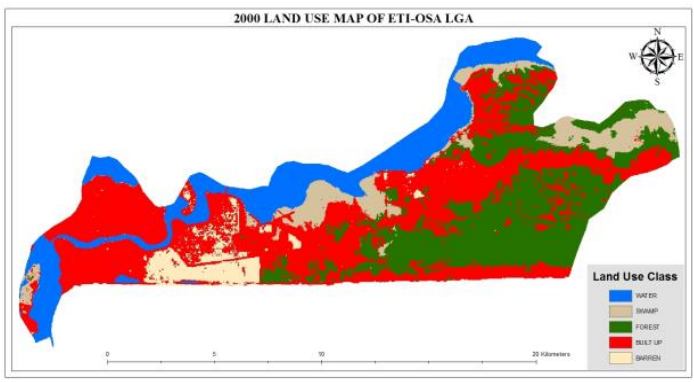

(b)

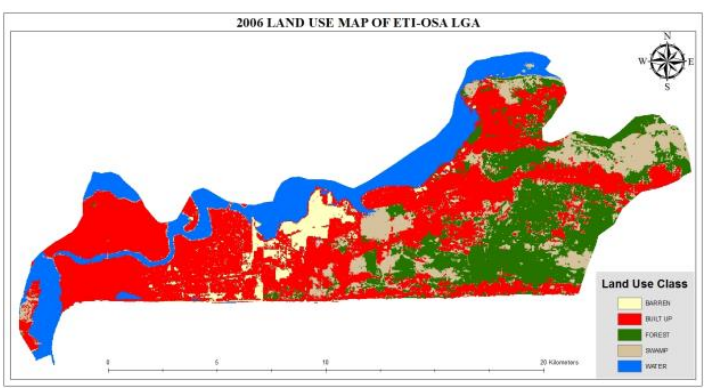

(d)

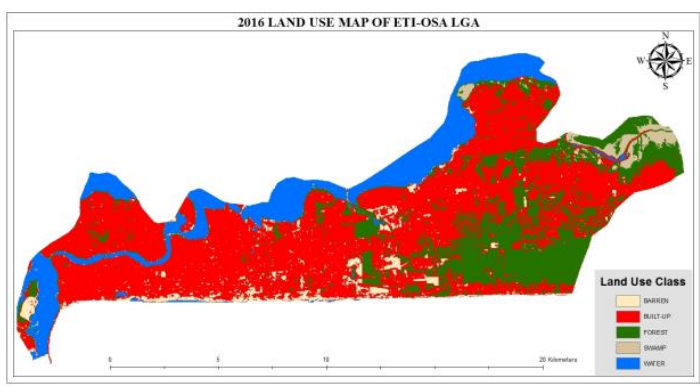

(f)

Figure 5: Land Use Classification Map (a) 1986 (b) 2000 (c) 2002 (d) 2006 (e) 2013 (f) 2016 


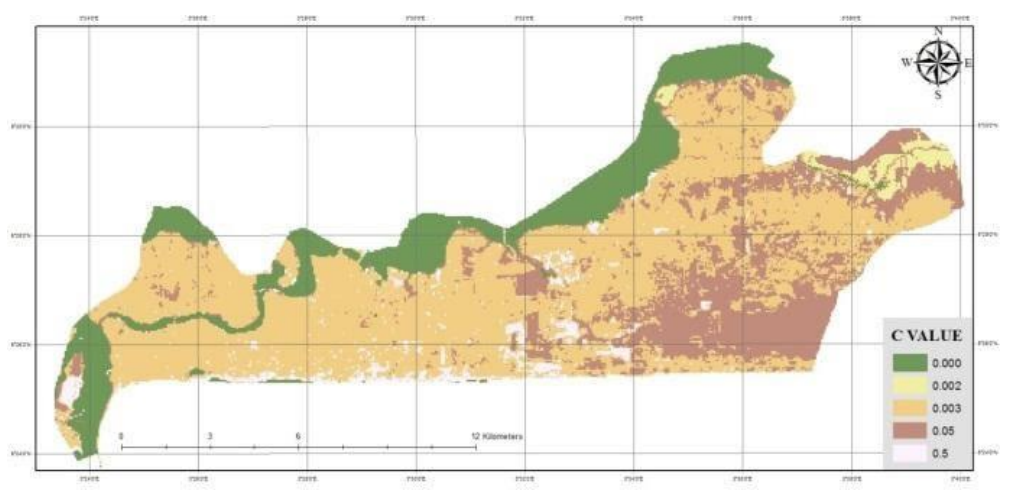

Figure 6: C Factor Map

\subsubsection{Support Practice Factor $(P)$}

Conservation practice factor $(\mathrm{P})$ in the RUSLE model (Figure 7) expresses the effect of conservation practices that reduce the amount and rate of water runoff, which reduce erosion. It includes different types of agricultural management practices such as: strip-cropping, contouring and terracing (Farhan et al., 2013). The $\mathrm{P}$ value range is between 0 to 1 where 0 represents very good man-made erosion resistance facility and 1 represents no man-made erosion resistance facility. The classification techniques performed on the images and thus a land use/cover management and support practice maps was produced. And subsequently, the cover management factor $(\mathrm{C})$ and support practice factor $(\mathrm{P})$ were estimated. $\mathrm{P}$ value is lower and less than 1 when the adopted conservation practice reduces soil erosion.

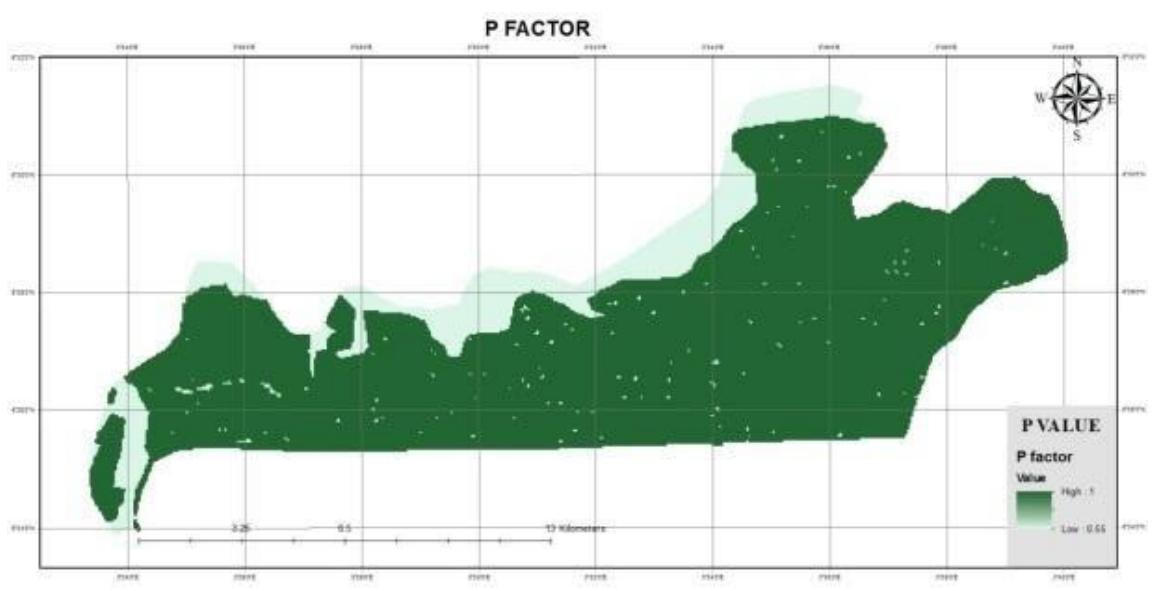

Figure 7: P Factor Map

\subsubsection{Questionnaire administration}

Structured questionnaires were administered to elicit information on the communities' perception of the causes and impact of erosion on the environment. Stratified random sampling and random sampling techniques were the sampling techniques used. The settlements were grouped into four strata based on the Local Council Development Area (LCDA/Ward) and then the questionnaires administered randomly in each stratum. Information obtained from the questionnaire administration were subjected to statistical analysis test using the Analysis of Variance (ANOVA) (Omodanisi et al., 2013) as shown in Tables 6 and 7. Also, focus group discussion was held with some of the occupants in the community with the view of acquiring information on the perceived causes and impact of erosion in the community. 
Table 6: Perception of occupant based on occupation

\begin{tabular}{|c|c|c|c|c|c|c|}
\hline Question & Grouping & Sum of Squares & $\mathrm{df}$ & Mean Square & $\mathrm{F}$ & Sig. \\
\hline \multirow{3}{*}{$\begin{array}{l}\text { How long have you } \\
\text { been living in your } \\
\text { community? }\end{array}$} & Between Groups & 10.292 & 4 & 2.573 & 2.242 & .066 \\
\hline & Within Groups & 218.046 & 190 & 1.148 & & \\
\hline & Total & 228.338 & 194 & & & \\
\hline \multirow{3}{*}{$\begin{array}{l}\text { What land is dominant } \\
\text { in your area? }\end{array}$} & Between Groups & 20.646 & 4 & 5.162 & 2.905 & 0.23 \\
\hline & Within Groups & 337.641 & 190 & 1.777 & & \\
\hline & Total & 358.287 & 194 & & & \\
\hline \multirow{3}{*}{$\begin{array}{l}\text { What do you } \\
\text { understand by erosion? }\end{array}$} & Between Groups & 7.570 & 4 & 1.893 & 3.898 & .005 \\
\hline & Within Groups & 92.245 & 190 & .486 & & \\
\hline & Total & 99.815 & 194 & & & \\
\hline \multirow{3}{*}{$\begin{array}{l}\text { Has there been any } \\
\text { incident of erosion in } \\
\text { the community }\end{array}$} & Between Groups & .708 & 4 & .177 & .701 & .592 \\
\hline & Within Groups & 48.010 & 190 & .253 & & \\
\hline & Total & 48.718 & 194 & & & \\
\hline \multirow{3}{*}{ If yes, Since when? } & Between Groups & 13.239 & 4 & 3.310 & 1.752 & .145 \\
\hline & Within Groups & 179.511 & 95 & 1.890 & & \\
\hline & Total & 192.750 & 99 & & & \\
\hline \multirow{3}{*}{$\begin{array}{l}\text { How often or what is } \\
\text { the frequency of } \\
\text { occurrence? }\end{array}$} & Between Groups & 16.140 & 4 & 4.035 & 2.106 & .086 \\
\hline & Within Groups & 182.050 & 95 & 1.916 & & \\
\hline & Total & 198.190 & 99 & & & \\
\hline \multirow{3}{*}{$\begin{array}{l}\text { What do you think is } \\
\text { the cause of the } \\
\text { erosion? }\end{array}$} & Between Groups & 3.982 & 4 & .995 & 1.370 & .250 \\
\hline & Within Groups & 69.008 & 95 & .726 & & \\
\hline & Total & 72.990 & 99 & & & \\
\hline
\end{tabular}

Table 7: Perception of occupant based on education

\begin{tabular}{|c|c|c|c|c|c|c|}
\hline Question & Grouping & Sum of Squares & $\mathrm{df}$ & Mean Square & $\mathrm{F}$ & Sig. \\
\hline \multirow{3}{*}{$\begin{array}{l}\text { How long have you } \\
\text { been living in your } \\
\text { community? }\end{array}$} & Between Groups & 17.626 & 4 & 4.406 & 3.973 & .004 \\
\hline & Within Groups & 210.713 & 190 & 1.109 & & \\
\hline & Total & 228.338 & 194 & & & \\
\hline \multirow{3}{*}{$\begin{array}{l}\text { What land is dominant } \\
\text { in your area? }\end{array}$} & Between Groups & 8.632 & 4 & 2.158 & 1.173 & .324 \\
\hline & Within Groups & 349.655 & 190 & 1.840 & & \\
\hline & Total & 358.287 & 194 & & & \\
\hline \multirow{3}{*}{$\begin{array}{l}\text { What do you understand } \\
\text { by erosion? }\end{array}$} & Between Groups & 6.965 & 4 & 1.741 & 3.563 & .008 \\
\hline & Within Groups & 92.850 & 190 & .489 & & \\
\hline & Total & 99.815 & 194 & & & \\
\hline \multirow{3}{*}{$\begin{array}{l}\text { Has there been any } \\
\text { incident of erosion in } \\
\text { the community }\end{array}$} & Between Groups & 1.197 & 4 & .299 & 1.196 & .314 \\
\hline & Within Groups & 47.521 & 190 & .250 & & \\
\hline & Total & 48.718 & 194 & & & \\
\hline \multirow{3}{*}{ If yes, Since when? } & Between Groups & 2.754 & 4 & .688 & .344 & .847 \\
\hline & Within Groups & 189.996 & 95 & 2.000 & & \\
\hline & Total & 192.750 & 99 & & & \\
\hline \multirow{3}{*}{$\begin{array}{l}\text { How often or what is } \\
\text { the frequency of } \\
\text { occurrence? }\end{array}$} & Between Groups & 12.000 & 4 & 3.000 & 1.531 & .199 \\
\hline & Within Groups & 186.190 & 95 & 1.960 & & \\
\hline & Total & 198.190 & 99 & & & \\
\hline \multirow{3}{*}{$\begin{array}{l}\text { What do you think is } \\
\text { the cause of the } \\
\text { erosion? }\end{array}$} & Between Groups & 2.088 & 4 & .522 & .699 & .594 \\
\hline & Within Groups & 70.902 & 95 & .746 & & \\
\hline & Total & 72.990 & 99 & & & \\
\hline
\end{tabular}

\subsection{Result and Discussion}

\subsection{Classified Images}

Figure 5 revealed that between 1986 and 2016, considerable changes had occurred in most parts of the area and that there was an expansion in the area cover by built-up from $21.65 \%$ to $41.03 \%$. Between 
2000 and 2002, the water body and the natural forest shrank from $17.8 \%$ to $17.19 \%$ and from $27.27 \%$ to $23.8 \%$ respectively. However, between 2002 and 2006, the built-up area increased from $42.9 \%$ to $45.28 \%$ reducing the water body and natural forest from $17.19 \%$ to $16.15 \%$ and $23.8 \%$ to $21.06 \%$ respectively. In the last three years of the study period (between 2013 and 2016), the built-up area and light forest expanded from $46 \%$ to 55.96 and $18.69 \%$ to $21.78 \%$ respectively, while the barren land and swamp reduced from $7.12 \%$ to $4.72 \%$ and 13.08 to $1.87 \%$ respectively. This is a very clear indication of increase in the human population of Eti-Osa.

\subsection{The Soil Loss Rate}

The data layers (maps) obtained for K, LS, R, C, and P factors of the RUSLE model were integrated to produce the erosion risk level (Figure 8) and then draped with cadastral map (Figure 9) in order to quantify, evaluate, and generate the potential soil erosion risk map for Eti-Osa LGA. In the study, the annual soil loss map of Eti-Osa was produced based on the combination of the RUSLE factors. For ease of interpretation, the value of the potential soil erosion risk was reclassified into 5 severity zones ranging from extreme to very low. The Soil erosion Map of Eti-Osa Local Government Area in figure 8 showed flashes of yellow, orange and red, which indicate moderate, high and extreme erosion sites. From result, it can be seen that the bare lands close to ocean and crop lands were mostly eroded. This can be attributed to the high rainfall and less vegetation cover to protect the soil. There are signs of erosion within the urban areas and sites close to the water body. The soil loss in the vegetated areas can be attributed to logging activities as noticed during field visits. When the area is deforested, the land is exposed and bare, the $\mathrm{C}$ and $\mathrm{P}$ value becomes high, posing huge erosion risks.

Most of the erosion hotspots were located around the Eti-Osa West (Lekki, Ajah settlements) which agrees with recent occurrence of erosion and ocean surge in Okun Alfa community. In this community, long and continuous human disturbance and deforestation, with the combined effect of $\mathrm{K}$, LS and C factors, account for high level of soil loss across the area. The areas with extreme severity clearly correlated with slope steepness. Other categories of high and moderate erosion were observed in some parts of Iru/Victoria Island. This can be ascribed as a result of percentage of gravel in Iru/Victoria Island. At Eti-Osa East and Ikoyi/Obalende, parts of Badore and Sangotedo areas seemed to record low losses which were largely due to the evenness of the topography, crop cover $\mathrm{C}$ and support practice factor $\mathrm{P}$. The type of soil in the area and more surface cover from developed urban environments, less logging, less open spaces and the urban factor could be another reason. Areas with a vegetal cover or some form of covering which could be infrastructure, buildings etc. can reduce the impact of erosion on the surface soil. In general, findings revealed that the land use type mostly affected were the waste land and the crop lands. The urban and vegetated/forested areas were least eroded or had low to moderate erosion though there are signs that the vegetated areas may be experiencing high erosion. The findings in this study agree with the research work of Ibitoye, (2010) who reported that land exposure and soil erosion in part of humid region of Southwest Nigeria had appeared to be an urban phenomenon and has been occurring at unprecedented rates.

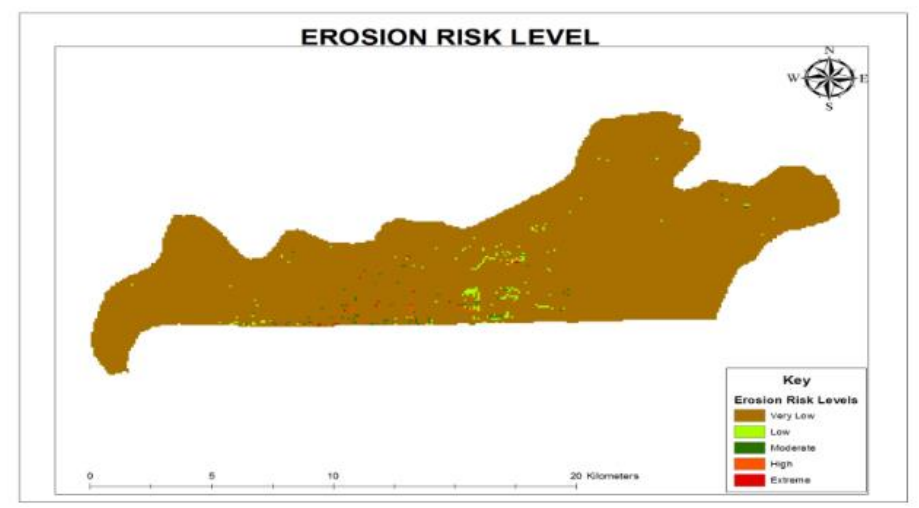

Figure 8: Erosion Risk Level 


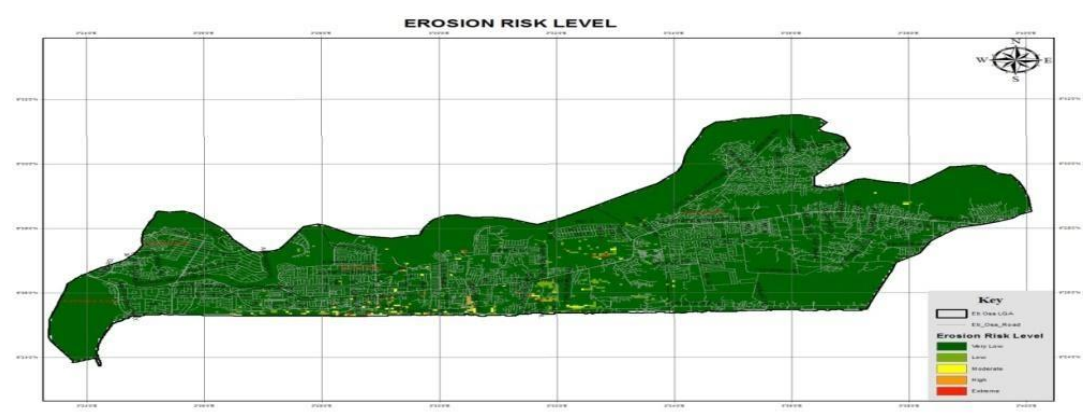

Figure 9: Erosion Risk Level draped with the Cadastral Map

\subsection{Questionnaire Result}

Occupant perception was analyzed through the administration of questionnaires. $40 \%$ of the occupants confirmed that there has been an incident of erosion in their community while $60 \%$ said there has not been any incident of erosion in their community. Over $25 \%$ of the occupants thinks the major cause of the erosion is poor drainage system, $5.2 \%$ thinks climate changes causes erosion in their community, $4.8 \%$ linked the cause of erosion to badly planned sea defenses while $2.4 \%$ thinks construction close to the sea and others factors contributed to the erosion in the community.

The result of the Analysis of variance (ANOVA) showed that the responses of the occupants were influenced by their occupation. The ANOVA result indicated a significant differences in the opinions of the respondents as regards what they perceived the term erosion $(\mathrm{P}=3.898, \mathrm{p}>0.005)$. That is, their occupation affected the way they responded to some of the questions. Also, the education of the respondents affected the way they perceived erosion. The significance value of how long they have lived in the community is 0.004 (i.e., $\mathrm{p}=0.004$ ), which is below 0.005 . Therefore, there is a statistically significant difference in how long they have lived in the community and their educational background. Previous research findings (Makinde, 2014; Tologbonse, 2018) have shown that factors such as education and occupation influence the way respondents perceive certain environmental challenge confronting their communities.

\subsection{Conclusion}

This research applied Remote Sensing and GIS techniques in erosion risk modeling in Eti-Osa LGA. The study was carried out in order to determine the major factors causing soil erosion the study area. The RUSLE model was combined with RS and GIS techniques to analyze the annual average soil loss rates caused by the various factors which influence soil erosion: rainfall, soil erodibility, topographical factors and the cover and support practices within the study area and to evaluate the spatial distribution of soil loss rates under different land uses.

It can therefore be concluded that high erosive rainfall, poor cover management, support practices, sand filling, land clearing in Eti-Osa for urbanization and infrastructure development have resulted in widespread soil erosion over the land surface. The extent of soil erosion occurring in the area is still increasing and is now a major cause for concern. From the results of the study, it can be concluded that combination of rainfall, lack of cover for the surface soil, were the major causes of soil loss in the study area.

\section{References}

Agada, BI, (2014) Rainfall Erosivity and Soil Erodibility at Makurdi, Benue State North-Central Nigeria, Department of Soil Science University of Agriculture Makurdi. An unpublished M.Sc. Thesis. 
Akoteyon, Isaiah \& Soladoye, O.. (2011). Groundwater Quality Assessment in Eti-Osa, LagosNigeria using Multivariate Analysis. Journal of Applied Sciences and Environmental Management. 15. 10.4314/jasem.v15i1.65687.

Alaaddin Y., Recep. and Abdullah E.A., (2008) Using the Remote Sensing and GIS Technology for Erosion Risk Mapping of KartalkayaDam Watershed in Kahramanmaras, Turkey.

Arnoldus H.M.J., (1980) An approximation of the rainfall factor in the Universal Soil Loss Equation M. De Boodt, D. Gabriels (Eds.), Assessment of Erosion, Wiley, Chichester, UK. pp. 127-132

Bojie F, Xilin W, Gulinck H, (1995) Soil erosion types in the Loess Hill and Gully area of China. J. Environ. Sci. Eng. 7:266-272.

Demirci A, and Karaburun A, (2012) Estimation of soil erosion using RUSLE in a GIS framework: a case study in the Buyukcekmece Lake watershed, northwest Turkey. Environmental Earth Sciences, 66 (3):903-913, https://doi:10.1007/s12665-011-1300-9.

ESRI, (2005) Environmental Systems Research Institute. http://www.esri.com retrieved 14/6/2013

Etuonovbe A., (2006) Administering Marine Spaces: The Problem of Coastal Erosion in Nigeria, a Case Study of Forcados South Point, Delta State. Coastal Processes, Tools and Planning, XXIII FIG Congress. Munich, Germany.

Fagbami A., (2000) Land degradation and rehabilitation. Proceeding of the 26th Annual conference of soil science society Nigeria (SSSN).

Farhan Y, Zregat D, Farhan I, (2013) Spatial Estimation of Soil Erosion Risk Using RUSLE Approach, RS, and GIS Techniques: A Case Study of Kufranja Watershed, Northern Jordan Journal of Water Resource and Protection, 2013, 5, 1247-1261 Published Online December 2013 (http://www.scirp.org/journal/jwarp).

Ganasri B.P., and Ramesh H, (2016) Assessment of soil erosion by RUSLE model using remote sensing and GIS - A case study of Nethravathi Basin. Geoscience Frontiers. V. 7(6): 953-961. http://www.glovis.usgs.gov/

Ibitoye M, and Eludoyin A, (2010) Land Exposure and Soil Erosion in part of Humid Region of Southwest Nigeria.FIG Congress, Sydney, Australia.

IPCC (2007) Climate Change 2007. Climate Change - Impacts, Adaptation and Vulnerability: Contributions of Working Group II to the Fourth Assessment Report of theIntergovernmental Panel on Climate Change. UK: Cambridge University Press, Cambridge, UK; accessed at http://www.ipcc.ch/pdf/assessment -report/ar4/wg 2 -spm-pdf.

Isikwue M.O., Abutu C, and Onoja S.B., (2012) Erodibility of Soils of the South West Benue State, Nigeria.Pacific Journal of Science and Technology.13(2):437-44.

Lee J.H., and Heo J.H., (2011) Evaluation of estimation methods for rainfall erosivity based on annual precipitation in Korea. Journal of Hydrology, 409 (1-2): 30-48, 10.1016/j.jhydrol.2011.07.031.

Makinde E.O., (2014) The Perception of Communities Prone to Environmental Degradation, 2nd Africa Regional Conference Technical Proceedings. Organization for Women in Science for the Developing World (OWSD) Organized under the Auspices of: University of Energy and Natural Resources (UENR), Sunyani, GHANA. 756-766.

Narain P, Khybri M.L., Tomar H.P.S., and Sindhwal N. S., (1994) Estimation of runoff, soil loss and USLE parameters for Doon Valley, Indian J. Soil Conserv., 22:1-9.

National Population Census (2006) Federal Republic of Nigeria Official Gazette Legal Notice on Publication of the details of breakdown of the National and State Provisional Totals. 
Odumosu T, Balogun Y, and Ojo K, (ed) (1999) Lagos State in Maps, Rex Charles Publication, Ibadan, pp1-50.

Omodanisi E.O., Eludoyin A.O., and Salami A.T., (2013) A Multi-Perspective View of the Effects of a Pipeline Explosion in Nigeria'. International Journal of Disaster Risk Reduction (IJDRR), Elsevier. 7 68-77. http://dx.doi.org/10.1016/j.ijdrr.2013.11.002, ISSN 2212-4209, U.K.

Pandey A, Chowdary V.M., Mal B.C., (2007) Identification of critical erosion prone areas in the small agricultural watershed using USLE, GIS and remote sensing. Water Resources Management. 21:729746.

Renard K.G., Foster, G.R., Weesies G.A., McCool D.K., and Yoder D.C., (1997) Predicting soil erosion by water: A guide to conservation planning with the Revised Universal Soil Loss Equation (RUSLE). Agriculture Handbook No.82 703.U.S. Department of Agriculture, Agricultural Research Service, Washington, District of Columbia, USA.

Roose E.J., (1977) Use of USLE to Predict Soil Erosion in West Africa. Special Publication No.21 Soil Conservation Society America, Ankeny, IOWA, pp. 60-74.

Sabins F.F., (1997) Remote Sensing and Principles and Image Interpretation.WH Freeman, New York.

Sazbo J, Pasztor L, Suba Z, Varallyay G, (1998) Integration of remote sensing and GIS techniques in land degradation mapping. Proceedings of the 16th International Congress of Soil Science; Montpellier, France, pp. 63-75.

Soo H.T., (2011) Soil Erosion Modeling using RUSLE and GIS on Cameron Highlands, Malaysia for Hydropower Development Published M.Sc. Thesis The School for Renewable Energy Science in affiliation with University of Iceland \& University of Akureyri, Akureyri.

Tologbonse A.S., and Makinde E.O., (2018) Variation detection and respondents' feedback: the cause, effect, and solution of oil spills. Geoinformatics FCE CTU, Indexed Platform: CrossRef., DOAJ. DOI:10.14311/gi.17.1.1.

Weesies G.A., (1998) Predicting soil erosion by water: A guide to conservation planning with the Revised Universal Soil Loss Equation (RUSLE). Agriculture Handbook No. 703. Washington, District of Columbia, USA.

Williams J.R., (1975). Sediment yield prediction with universal equation using runoff energy factor. Agricultural Research Service report ARS-S-40. U.S. Department of Agriculture.

\section{Cite this article as:}

Makinde E.O and Oyebanji E.I., 2020. Remote Sensing and GIS Application to Erosion Risk Mapping in Lagos. Nigerian Journal of Environmental Sciences and Technology, 4(1), pp. 40-53. https://doi.org/10.36263/nijest.2020.01.0081 